\title{
Parasites and Morphometric Indices of Frozen Fish Sold in Nsukka Urban Market, Enugu State, Nigeria
}

\author{
${ }^{1}$ Okoye, I. C., ${ }^{2}$ Obiezue, R. N. N., ${ }^{3}$ Dakul, D. A. and ${ }^{4}$ Nwadike, P. O. \\ ${ }^{1,2,4}$ Parasitology and Public Health Research Unit, Department of Zoology, University of Nigeria, Nsukka, Enugu \\ State, Nigeria. \\ ${ }^{3}$ Applied Parasitology Unit, Department of Zoology, University of Jos, Plateau State, Nigeria.
}

Corresponding author: Okoye, I. C. Parasitology and Public Health Research Unit, Department of Zoology, University of Nigeria, Nsukka, Enugu State, Nigeria. Email: ikemchriso@yahoo.co.uk Phone: +2348069284633

\begin{abstract}
The parasites and morphometric indices of frozen fish sold in Nsukka Urban Market in Nsukka Local Government Area of Enugu State, Nigeria were investigated between June and December 2008 to determine the parasite prevalence, mean intensity and abundance and some morphometric indices associated with parasitism. Two species of acanthocephalan endo-parasites were isolated from Savreda sp namely, Gorgorhynchus sp and Paragorgorhynchus sp with overall prevalence of $35.4 \%$. The mean intensity for Gorgorhynchus sp was $14.1+0.2$ and the mean abundance was $10.0 \pm 0.1$. Paragorgorhynchus sp had mean intensity of 1.2 \pm 0.1 and mean abundance of 10.0 \pm 0.1 . Some morphometric characteristics were calculated to correlate weight against standard length (SL) and total length (TL). There was a significant correlation between mean $S L(2.76+0.59 \mathrm{~cm})$ and mean $T L(3.23+0.15 \mathrm{~cm})$ with mean body weight $(B W=320+0.49 \mathrm{~g})$ for Sardinella sp and mean $S L(32.6+0.71 \mathrm{~cm})$ and $T L(35.9+0.66 \mathrm{~cm})$ with mean $B W(440+0.13 g)$ for Savreda sp. The mean condition factor $(K)$ fell in $0.01 \pm 0.001$ in both species, this shows that the fish overall condition is in a good state, whereas $b$-value $(b=1.7)$ shows that the Savreda sp which hosted parasite had a negative allometric growth pattern $(b<3)$. Sardinella sp had $b$-value $(b-$ value $=3.37)(b>3)$ showing a positive allometric pattern. The negative allometric pattern for Savreda $s p$ is probably as a result of the parasites they hosted.
\end{abstract}

Keywords: Parasites, Morphometric Indices, Frozen fish

Introduction

The world is presently witnessing soaring population and scarce resources. There is therefore, a high demand for protein. Due to the high cost of beef, fish has emerged as a source of essential animal protein as it is relatively cheap, affordable and available. Fish oil is a natural source of minerals like omega-3-essential amino acid necessary for healthy heart, functioning brain and immune system (Horn, 1999). Among its health and nutritional values is its constituent polyunsaturated fatty acid which aids in lowering blood cholesterol level.

Unfortunately, parasites and diseases are denying man adequate supply of this food source. The issue of fish parasite and disease has posed serious challenge to fish biologists and aquaculturists. It is an issue of both health and economic concern. The zoonotic diseases that result from the consumption of raw and uncooked fish include clonorchiasis, opisthorchiasis, diphyllobothriasis, gnathosomiasis and anisakiasis (Ko, 1995).

Fish mortalities and attendant economic losses occur during attack by helminth parasites, bacteria, monogenian and crustacean parasites. In addition to hampering organ metabolism in fish, the rate at which this incidence build up to epizootic proportion is alarming and requires attention from both the fish biologists, public health epidemiologists and authorities in charge of agriculture.

Studies have revealed rich parasitic fauna in marine fishes (Grabda, 1991) ranging from ectoparasites (Oniye et al; 2004) to endoparasites
(Auta et al., 1999) which affect fish health, growth and survival. Fish accommodate most parasites as intermediate hosts, which could infest fish-eating animals like man, where they parasitize to complete their life cycles. The parasites cause damages to organs and tissues, often resulting to ill health and death in extreme conditions, without adequate care. Often, this happens when the food source is not well cooked.

Studies involving marine fish parasites reveal that the economically important parasitic groups include the micro parasites viz. viruses, bacteria, fungi, protozoans and myzozoans while the macro parasite group comprised of helminthes such as monogenea and the Digenea trematodes (flukes), cestodes (tape worms), Nematodes (round worms) and Acanthocephalan (thorny headed worms). The Arthropod parasites are represented mainly by the copepods (Marcogliese, 2001, 2002).

This study investigated the morphometric indices and parasitic fauna of frozen fish brought in for sale to local consumers at an urban market. It is hoped that the findings would reveal the community health implications of the sale and consumption of frozen fish in Nigeria.

\section{Materials and Methods}

Study area: The study area is Nsukka Local Government Area (LGA) of Enugu State. The LGA is located about $60 \mathrm{~km}$ northwest of Enugu, the capital city of Enugu State. The area is located between latitude $6^{\circ} 44^{1}$ and $7^{\circ} 00^{1} \mathrm{~N}$ and longitudes $6^{\circ} 14^{1}$ and $7^{\circ} 35^{1}$. The LGA covers an area of about $475 \mathrm{~m}^{2}$ and is bounded by Igbo-Eze north LGA to 
the north, Uzo-Uwani, LGA to the West, Igbo Etiti LGA to the south and Isi-Uzo and Udenu LGAs to the east.

Nsukka Local Government Area has a total population of 220,411 , and a population density of 455 persons per square kilometer (Nigerian Congress, 2006). Nsukka urban has a population of 69,230 persons and a density of 146 per square kilometer. The urban city is endowed with basic amenities like electricity, pipe-borne water, hospitals, post office and several educational institutions including the famous University of Nigeria. In addition, it has a major open market, the Ogige main market. There is a cold room a few kilometers away, where the frozen fish are kept before being supplied to the retailers.

The mean annual temperature is about $27^{\circ} \mathrm{C}$. The climate is typically tropical with well defined wet season from April to October and dry season, between November and March (Oformata and Phil-Eze, 2001). The dominant human activity in the study area is agriculture. Crops usually cultivated include yam, cassava, maize, cocoyam etc.

Sample collection and identification: Samples of the various frozen fish species sold at the Ogige main market, Nsukka were obtained for this study between June and December, 2008. The fish specimens were transported to the Parasitology and Public Health Laboratory of the University of Nigeria, Nsukka and preserved under refrigeration prior to identification and analysis. The procedure for examining fish for parasites by Marcogliese (2002) was used.

\section{Morphometric measurements and sex determination: The total length (TL), standard length (SL) and eye diameter were measured to the nearest $0.1 \mathrm{~cm}$ using a meter rule measuring board. The weights of the fish were measured to the nearest $0.1 \mathrm{~g}$ using a top loading meter PC 2000 electronic weighing balance. The fish were dissected with a dissecting scissors for sex determination by the presence or absence of testes or ovaries. Presence of testis indicated maleness, whereas ovary indicated a female fish.}

Examination of fish specimens for parasites: The external body surfaces viz. scales, gills, fins, opercula and eye were examined for ecto-parasites with the aid of a hand lens and then, the fish was de-scaled and the scales kept in normal saline in a Petri dish to dislodge any parasite present.

The internal organs viz. eosophagus, small intestine, large intestine, stomach, liver, spleen, etc were dissected and searched for endo-parasites. The organs were then placed in normal saline in different petri dishes including parasites isolated from those regions. Thick and thin blood smears were made with blood obtained from the heart and gills for haemoparasites.

Treatment, fixation and preservation of parasites: The treatment, fixation and preservation of parasites followed the procedure employed by Ash and Orihel (1991). The worms isolated, were placed in normal saline to clear mucus and other host debris. They were then fixed in $10 \%$ formalin. The parasites were later mounted on a permanent slide using Canada balsam. Treatment of microparasites also followed the procedure adopted by Ash and Orihel (1991). Blood and tissue smears from scrapping of various organs were made on glass slides, allowed to air dry, fixed in absolute methanol for 5 seconds and stained in Giemsa for 45 minutes. Smears were later examined at X400 oil emersion.

Statistical analysis of data: The length-weight relationship and condition factors were determined using the formula: $\mathrm{W}=\mathrm{aL}^{\mathrm{b}}$ Where $W=$ weight of fish (g); $L=$ length of fish $(\mathrm{cm})$ while $a$ and $b$ are constants obtained from the regression equation of $W$ and $L$. The logarithmic transformation of the formula (log $W=\log a+b \log L$ ) was used to calculate the constants $a$ and $b$. Fulton's condition factors $(K)$ for each fish species was calculated suing the formula $\mathrm{K}=100 \times \mathrm{W} / \mathrm{L}^{3}$ (Ezenwaji and Offiah, 2003). Where $W$ and $L$ are the weight (g) and length $(\mathrm{cm})$ respectively. Parasites recovered were analyzed using the infection statistics of Bush et al. (1997).

\section{Results}

The pattern of distribution of the common morphometric characteristics among the fish species examined is shown on Table 1. Sardinella species had shorter mean SL $(27.6 \pm 0.59 \mathrm{~cm}), \mathrm{TL}$ $(3.23 \pm 0.15 \mathrm{~cm})$ and lower mean BW $(3.2 \mathrm{~kg} \pm 0.59$ $\mathrm{kg})$ while savreda species was longer in mean SL $(32.6 \pm 0.71 \mathrm{~cm})$, mean TL $(35.9 \pm 0.66 \mathrm{~cm})$ and higher in mean BW (4.4+0.13). Statistically, the length and weight distribution were significantly correlated $(p<0.05)$.

The mean condition factor $(K)$ for the fish species shows that the mean $K$ value fell in $0.01 \pm 0.01$ in both species. Distribution of mean bvalue shows that Savreda is negatively allometric (1.77) $(\mathrm{b}<3)$ while Sardinella $\mathrm{sp}$ is positively allometric $(b=3.37)(b>3)$. The mean $K$ value is the same in the two species $(0.01 \pm 0.0)$. This shows significance $(p<0.05)$.

The length-weight relationships of the two species are represented in Table 2. The table presents the total length-weight and standard length-weight relationship of the fish species. The $\mathrm{SL}, \mathrm{TL}$ and BW were closely correlated in the two species.

Table 3 shows the standard length-weight relationship between the fish species and the regression $\left(r^{2}\right)$ values. Sardinella species (3.57) (TL-BW) and Savreda (0.82) (TL-BW), including a and $b$ values, and the significance values for the fish species.

Table 4 represents the parasites recovered during the study, their prevalence, sites of isolation, mean intensity and mean abundance. The fish parasites recorded were Gorgorhychidae species which were isolated from the intestine and stomach regions and the Paragorgorhynchus species which were isolated from the intestines of the fish host. 
Table 1: Morphometric measurements, mean condition factor (k) and mean b-values of fish species sold at the Nsukka Urban Market (June to December, 2008)

\begin{tabular}{lcccccc}
\hline Fish species & $\begin{array}{c}\text { Number } \\
\text { examined }\end{array}$ & $\begin{array}{c}\text { Mean } \\
\text { SL }(\mathbf{c m})\end{array}$ & $\begin{array}{c}\text { Mean } \\
\text { TL (cm) }\end{array}$ & $\begin{array}{c}\text { Mean } \\
\text { BW (g) }\end{array}$ & $\begin{array}{c}\text { Mean } \\
\text { condition }\end{array}$ \\
\hline Sadinella spp & 24 & $27.6+0.01$ & $32.3+0.14$ & $320+0.49$ & $0.01+0.001$ & $3.37+0.05$ \\
Savreda spp & 24 & $32.6+0.71$ & $35.9+0.06$ & $440+0.13$ & $0.01+0.001$ & $1.17+0.20$ \\
\hline
\end{tabular}

Table 2: Length - Weight relationship (LWR) and related statistics of fish species sold at the Nsukka Urban Market (June to December, 2008) using Total Length

\begin{tabular}{|c|c|c|c|c|c|c|c|c|}
\hline \multirow[t]{2}{*}{ Fish species } & \multirow[t]{2}{*}{ Number examined } & \multicolumn{3}{|c|}{ Total Length $(\mathrm{cm})$} & \multicolumn{3}{|c|}{ LWR } & \multirow{2}{*}{$\begin{array}{c}\text { p- } \\
\text { value }\end{array}$} \\
\hline & & Mean +SD & Min & Max & a & b & $r^{2}$ & \\
\hline Sandinella spp & 24 & $1.50+0.01$ & 30.1 & 35.5 & $4.0 \times 10^{-5}$ & 3.18 & 0.62 & 0 \\
\hline Savreda spp & 24 & $1.55+0.06$ & 28.2 & 42 & $6.0 \times 10^{-3}$ & 1.83 & 0.81 & 0 \\
\hline
\end{tabular}

Table 3: Length - Weight relationship (LWR) and related statistics of fish species sold at the Nsukka Urban Market (June to December, 2008) using Standard Length

\begin{tabular}{|c|c|c|c|c|c|c|c|c|}
\hline \multirow[t]{2}{*}{ Fish species } & \multirow{2}{*}{$\begin{array}{l}\text { Number } \\
\text { examined }\end{array}$} & \multicolumn{3}{|c|}{ Standard Length (cm) } & \multicolumn{3}{|c|}{ LWR } & \multirow{2}{*}{$\begin{array}{c}\mathrm{p}- \\
\text { value }\end{array}$} \\
\hline & & Mean +SD & Min & $\operatorname{Max}$ & $\mathbf{a}$ & b & $r^{2}$ & \\
\hline Sandinella spp & 24 & $1.44+0.01$ & 30.1 & 35.5 & $2.2 \times 10^{-5}$ & 3.57 & 0.7 & 0 \\
\hline Savreda spp & 24 & $1.50+0.07$ & 28.2 & 42 & $1.1 \times 10^{-2}$ & 1.71 & 0.81 & 0 \\
\hline
\end{tabular}

$a=$ intercept $; \quad b=$ slope $; r^{2}=$ regression coefficient

Table 4: Parasite species and their sites of isolation in frozen fish sold at the Nsukka Urban Market $(n=48)$

\begin{tabular}{lccc}
\hline Parasite species & $\begin{array}{c}\text { Site of } \\
\text { isolation }\end{array}$ & $\begin{array}{c}\text { Mean } \\
\text { intensity }\end{array}$ & $\begin{array}{c}\text { Mean } \\
\text { abundance }\end{array}$ \\
\hline Gorgorhynchus spp & $\begin{array}{c}\text { Intestine \& } \\
\text { stomach }\end{array}$ & $1.2+0.1$ & $10.0+0.1$ \\
Paragorgorhynchus spp & $\begin{array}{c}\text { Intestine } \\
\text { Inten }\end{array}$ & $14.1+0.2$ & $10.0+0.1$ \\
\hline
\end{tabular}

The overall prevalence rate of parasite infection was $35.4 \%$ and mean intensity was 14.1 parasites/fish host. All the parasites were isolated from Savreda species while the Sardinella were parasite-free. There was no difference in parasite infection according to host sex

\section{Discussion}

Only the Savreda sp haboured parasites, the acanthocephalans (spiny-headed worm), whereas the Sardinella species were parasite free. The recovery of large community of endoparasites in the Savreda sp could be due to the fish diet. Large population of crustacean amphipods were recovered from the stomach and this crustacean were required for the worms to complete their life cycle. (Miller and Harley, 1996).

This crustacean must serve as a veritable vehicle for transporting the worms to their host. Guidelli et al (2003) observed that host feeding habit/diet were important in helminth acquisition. Diets play a major role in the composition of parasite communities in fish gut, with richest enteric helminth fauna found in fish with mixed carnivorous diet.

Sardinella species was parasite-free. The absence of endoparasites can be as a result of the species herbivorous feeding habit.

It was observed that fish with larger body weight $4.4+0.13$ and highest total length $35.9+0.06$ had the highest parasite prevalence of $70.8 \%$ in Sarvreda sp. Other studies found a positive correlation between parasite abundance and host body size (Morrand, 2000).

The growth patterns of the species are impressive with mean b-value ranging from 1.773.37 for Savreda and Sardinella respectively.

The coefficient of regression $\left(r^{2}\right)$ is high for savreda 0.82 , this meant that $82 \%$ of (TL) can be predicted by weight of the fish, and 0.62 for Sardinella sp, showing that $62 \% \quad(T L)$ is dependent on fish weight. The mean condition factors of the two species are high; this proved that the fishes are in a very good growth condition.

It was observed that occurrence of parasite did not affect the fish condition factor, thus the fish were adapted to the effects of the parasites at the existing intensity. Higher parasite intensity is expected to alter the equilibrium. The non recovery of ecto parasites from scales, gills, fins, mouth cavity and from area under eye sockets is of interest to fisheries biologist and needs more investigation.

We recommend proper cooking of frozen fish before consumption. Also, the stomach and intestine of the fish should be discarded properly. Parasites are shown to have higher preference for fish gut. This area should therefore, always be discarded and not consumed.

\section{References}

Ash, L. R. and Orihel, T. C. (1991). Parasites: A guide to laboratory procedure and identification. ASCP Press, Chicago.

Auta, J., Oniye, S. J. and Adakola, J. A. (1999). The helminth parasites of gastrointestinal tract of synodontis species in Zaria, Nigeria. Journal of Pure and Applied Science, 2(2): 47-53.

Bush, A. O., Lafferty, K. K., Lotz, J. M. and Shostak, A. W. (1997). Parasitology meets ecology on it's own terms: Margolis et al revisited. Journal of Parasitology, 83: 575-583.

Ezenwayi, H. M. G. and Offiah, F. N. (2003). The Biology of Pellonula leonensis Boulenger, 
1916 (Osteichthyes: clupeidae) in Anambra River, Nigeria. Journal of Biological research and Biotechnology, 1(2): 33-50.

Grabda, J. (1991). Marine Fish Parasitology: An outline. Polish Scientific Publishers Warszawa. 306 pp.

Guidelli, G. M., Isaac, A., Takemoto, R. M. and Pavanelli, G. C. (2003). Endoparasite infracommunities of Hemisorubuim platyrhychas (valenciennes, 1840) (pisce: pimelodidae) of the Baia river, upper Panama, Brazilian Journal of Biology, 63(2): 261-268.

Horn, S. (1999). Essential fatty acid http://www.nutritionsupplement.com/s/fatty acid.htm Accessed 20 $0^{\text {th }}$ June, 2008.

Ko, R.C (1995). Fish borne parasitic zoonosis. In: P.T.K Woo (Ed.) Fish diseases and disorders. Vol. 1: Protozoan and Metazoan infections. Cambridge. CAB International. $808 \mathrm{pp}$.

Marcogliese, D, J. (2001). Parasites of fishes in freshwater. http://www.emanerese.html Accessed June, 2008.

Marcogliese, D. J. (2002). Parasites of fishes in fresh water. Ecological Monitoring and
Assessment Network (EMAN) Parasitology Module Steering Committee, Parasitology Section, Canadian Society of Zoologists. http://www.eman.rese.ca Accessed on $20^{\text {th }}$ June, 2008.

Miller, S. A. and Harley, J. P. (1996). Zoology, $3^{\text {rd }}$ ed. McGraw Hill, London. 752 pp.

Morrand, S. (2000). Wormy World: Comparative test of theoretical hypothesis on parasite species richness. pages 63-79.In Poulin, S and Skorping, A. Morand, S.(eds.), Evolutionary biology of host-parasite relationship: Theory meets reality. Elsevier Science, Amsterdam.

Oformata, G. E. K. and Phil-Eze, P. O. (2001). Geographical perspectives on Environmental problems and Management in Nigeria. Jamoe Enterprises. (Nig). Enugu 327 pp.

Oniye, S. J., Adebote, D. and Ayanda, A. I. (2004). Helminth parasites of Clarias gariepinus (Teugels) in Zaria, Nigeria. Journal of Aquatic Sciences, 19(2): 17-75.

The Nigeria Congress: Administration Levels, the 774 Local Government Areas. Retrieve from www.nigeriacongress.ng/fgn/administrative/lgadetail.asp?g=nsukka 